\title{
Local changes in community diversity after coral transplantation
}

\author{
Helen T. Yap* \\ The Marine Science Institute, University of the Philippines, Diliman, 1101 Quezon City, Philippines
}

\begin{abstract}
Over several decades, coral transplantation has been developed as a tool to rehabilitate damaged coral reef habitats. This investigation aimed to determine whether this form of intervention would result in a significant improvement in diversity and abundance of associated reef species. The experiment consisted of 4 treatments: undisturbed sites (which also served as sources of the transplants), degraded plots to which corals were transplanted, empty plots that received no transplants, and control plots that were empty and situated at least $100 \mathrm{~m}$ away from the transplant and empty plots. The latter 3 treatments were replicated at 4 different sites. The establishment or movement of fish and invertebrates, as well as the abundance of algae, were recorded on a quarterly basis. Both non-metric multidimensional scaling and repeated measures ANOVA detected significant differences among treatments, with transplant plots having higher numbers and abundances of taxa than the empty plots and the empty controls. The 2 latter treatments did not differ significantly from each other. The source sites had higher abundances of coral recruits (Poritidae) than all the other treatments and of sea urchins (Diadematidae) than the empty plots and empty controls. The transplant plots harbored greater numbers of damselfish (Pomacentridae) and sea urchins than the empty plots and empty controls. Thus, coral transplantation resulted in higher diversity and greater abundance of fish and invertebrates and has the potential to help re-establish degraded reef communities.
\end{abstract}

KEY WORDS: Coral transplantation $\cdot$ Coral restoration $\cdot$ Biodiversity

Resale or republication not permitted without written consent of the publisher

\section{INTRODUCTION}

Coral reefs are significant shallow-water ecosystems in tropical regions of the world which are currently being degraded at alarming rates (Nyström et al. 2000, Bruno \& Selig 2007). The transplantation of scleractinian corals is now widely regarded as a potentially useful tool for the restoration of damaged reef habitats (Rinkevich 2005, Edwards \& Gomez 2007). However, habitat restoration can be considered successful only if the established community possesses structure and function similar to a naturally occurring one (Lockwood \& Pimm 1999). The corals contribute to the primary physical structure of the reef community (Pandolfi \& Jackson 2006). Coral cover on a typical reef is a mixture of live and dead colonies in varying proportions. The community they support is composed of a diverse range of species including other invertebrates, algae, microbes and fishes.

Corals are able to provide shelter and refuge areas (Sano et al. 1984) by virtue of their 3-dimensional relief. Habitat complexity is an important factor that contributes to the abundance, occurrence and persistence of marine organisms (Adams \& Ebersole 2002). The formation and stabilization of fish communities, for example, is sustained in part by this 3-dimensional relief (Öhman et al. 1997, Connell \& Kingsford 1998, Öhman \& Rajasuriya 1998, Cabaitan et al. 2008). Moreover, empirical evidence has established a link between 3-dimensional relief and the abundance and types of various coral reef organisms (Lindahl et al. 2001). The density of certain fishes that reside among coral branches has been observed to decrease with reduction of the latter (Sano et al. 1984, Syms \& Jones 
2000). Roving herbivores and visiting fish (Sano 2001) are also associated with structural relief (e.g. the scarid fish Scarus iserti; Adams \& Ebersole 2002).

Although the structural attributes of corals influence reef community assembly, the importance of the living component of the coral (i.e. the animal tissue with the associated algal symbionts) should not be overlooked. Without the live component, the structure becomes susceptible to erosion from bioeroders and water turbulence (Lindahl et al. 2001). Furthermore, corals provide a more suitable substrate when compared with non-living, artificial marine habitats (Carr \& Hixon 1997). For many organisms there is a preference for settling on living corals (Booth \& Beretta 2002) instead of on non-living substrates. Thus, there are significant differences in the community structure and composition that develop around living corals compared with dead colonies. In addition, living coral will continue to deposit calcium carbonate over time, thus ensuring the growth of the physical structure supporting the reef community in the long term.

The focus of coral transplantation experiments to date has mostly been on the responses of transplanted coral colonies themselves to their new environments (e.g. Yap et al. 1998, Yap \& Molina 2003). Neighboring and associated organisms have received minimal attention. Changes in the community assemblage after transplantation have been studied in other marine systems such as algal habitats (Carr 1989, Levin \& Hay 2002) and boulder fields (Chapman 2002). In coral reefs, studies on the effects of transplantation on coralassociated species have dealt largely with fish assemblages (Hixon \& Carr 1997, Lindahl et al. 2001, Cabai$\tan$ et al. 2008).

This study focuses on short-term community changes within localized patches in a reef environment after the introduction of coral transplants. The aims of this study are to: (1) document changes in richness and abundance of various reef taxa after coral transplantation over different temporal and spatial scales; and (2) compare patterns between sites with and without coral transplants.

\section{MATERIALS AND METHODS}

Location and experimental design. Study sites were established in 4 shallow reef flat areas around Lipata Island located in Tayabas Bay, southeastern Luzon, the Philippines (Fig. 1). These sites have a depth range of 1.5 to $3 \mathrm{~m}$ and are characterised by barren rocky substrates interspersed with patches of sand and rubble. Two sites are located on the southwestern side of the island while the remaining 2 are found on the eastern side. The observable difference between the 2 sides of

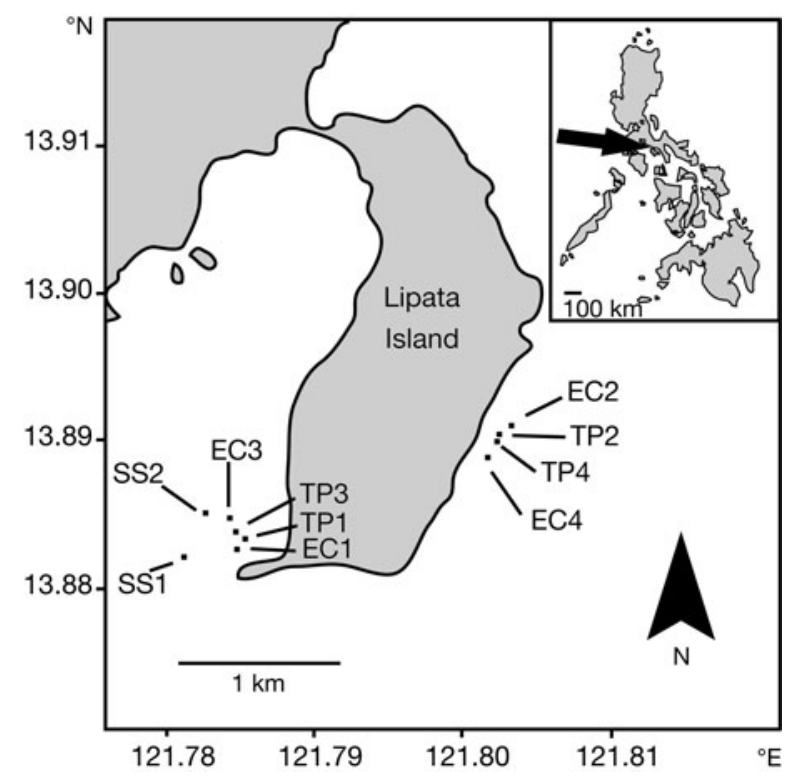

Fig. 1. Location of study sites 1 to 4 and treatments. SS = source site, $\mathrm{TP}=$ site containing transplant plots (interspersed among the empty plots), $\mathrm{EC}=$ site containing empty controls (situated at least $100 \mathrm{~m}$ from transplant and empty plots). Inset shows location of Lipata Island

the island is the relative exposure of the eastern side of the island to wind and waves, bringing about greater water turbulence and a higher suspended sediment load throughout the year. Each site contained 3 experimental treatments with 6 replicates each: transplant plots (TP), empty plots (E) and empty controls (EC). Each replicate was $1 \mathrm{~m}^{2}$ in area.

On the basis of visual assessment, plots in all 3 treatments within a site were structurally similar to each other at the start of the experiment with very low live coral cover $(<10 \%)$. In the TP treatment, 3 coral species were transplanted to each $1 \mathrm{~m}^{2}$ plot: Acropora palifera, a submassive species with thick branches $(\mathrm{n}=2$ per plot), Porites cylindrica, a branching species $(\mathrm{n}=2)$, and Porites lobata, a massive form $(\mathrm{n}=3)$. They were collected from a nearby reef (Fig. 1) described below. Colonies were carefully pried off the reef surface or other attached organisms with a hammer and chisel. Initial long diameters of the transplants were as follows: 5.3 to $19.3 \mathrm{~cm}$ for A. palifera, 11.4 to $30.1 \mathrm{~cm}$ for P. cylindrica, and 7.4 to $18.5 \mathrm{~cm}$ for P. lobata. The transplants were put into water-filled plastic bins and transferred by boat to the transplant sites. Each transplant site contained 6 transplant plots $1 \mathrm{~m}^{2}$ in area and spaced 2 to $10 \mathrm{~m}$ apart.

The transplants were attached to bare rock surfaces by means of cement. Exceptions were Sites 1 and 2, where half of the plots were covered instead with green plastic screens to which the transplants were 
tied. The survival and growth of the coral transplants are the subjects of a separate study. The transplantation of whole colonies is generally discouraged, except in extreme situations such as the need to relocate entire reef patches or communities.

E plots were interspersed among the TP plots. The EC plots were situated at least $100 \mathrm{~m}$ away from the first 2 treatments to minimize interaction of organisms between the E and EC treatments. Thus, the spatial scale examined ranged from a single square meter to tens and then hundreds of square meters.

Sites 1 (southwest) and 2 (east) were established in April 2000 and October 2000, respectively. Sites 3 and 4 were set up in April 2001 and November 2001, respectively. Undisturbed plots $(n=6)$ constituted a 4 th treatment. They also measured $1 \mathrm{~m}^{2}$ each in area and were located on a forereef slope in the southwest part of Lipata Island. These are labeled source sites (SS). The purpose of the SS treatments was to determine whether the experimental plots containing coral transplants (TP) would differ significantly from intact reef areas in terms of establishment or movement of species. The SS were situated within large patches of the 3 species used for the experiment and from which the transplants were derived. Depths along the slope varied from 4 to $9 \mathrm{~m}$. Distances between plots ranged from 2 to $10 \mathrm{~m}$.

Field observations. The appearance of algae, invertebrates and fish at the experimental and control sites was monitored by visual census of all plots during quarterly field visits. Underwater, the observers approached the plots with unobtrusive and slow movements so as to cause minimal disturbance to the organisms within the plots. The number and length of fast moving organisms (i.e. fish) were estimated from a distance. Grazing schools of fish (e.g. plotosids) were excluded from the observations as these contributed to the occurrence of outliers in the data. Recording of the slower moving (e.g. sea urchins) and/or sessile (e.g. boring clams) organisms was done at a closer distance. Algae, cyanobacteria, sea grasses and sponges were quantified in terms of percentage cover while other organisms were recorded as numbers. Corals were counted when they appeared as new recruits. Recruits were defined as small colonies visible to the naked eye. The coral transplants were not included in the census of organisms.

Of the biota in the treatment plots at the 4 sites, fish were grouped into families, while benthic organisms were classified into 31 coarse taxonomic groups (e.g. scleractinians, rhodophytes, bivalves, echinoids) (Table 1). Monitoring was conducted from January 2001 to July 2002 at 3 mo or quarterly intervals: 7 intervals for Sites 1 and 2, 5 intervals for Site 3, and 4 intervals for Site 4 .
Statistical analyses. To test for possible changes in microhabitat diversity due to the introduction of coral transplants, non-metric multidimensional scaling (nMDS) using the Bray-Curtis similarity index was employed (Clarke 1993, Clarke \& Gorley 2001). Data were arranged with the total number of taxa per treatment plotted across time. They were square-root transformed to minimize bias due to highly abundant species. One-way analysis of similarities (ANOSIM, Clarke 1993, Clarke \& Gorley 2001) was used to test for significant differences among treatments and over time. This was followed by a test of similarities in percentages (SIMPER, Clarke 1993, Clarke \& Gorley 2001) to determine which groups of organisms contributed most to the similarity within treatments as well as to the differences among treatments.

As an additional test to confirm whether the differences among treatments and over time were significant, both fish and benthic diversity data sets were subjected to repeated measures ANOVA (Potvin et al. 1990). This was the appropriate statistical test for the diversity data since the study involved repeated visits to, and monitoring of, the same plots over time. Only fish and invertebrates were used for this analysis because abundance as count data was determined only for these groups. The abundance of algae, on the other hand, was assessed in terms of percentage cover, which is not directly comparable with abundance in terms of numbers.

Three monitoring months were included in these analyses since these were the only times when data for all plots were complete, namely January, April and July in 2002. Because of an unbalanced data set, the SS plots were excluded from the analyses. For the other sites, the quarterly surveys covered by the analyses were the last 3 shown in Figs. 2 \& 3.

\section{RESULTS}

\section{General trends in fish and invertebrate composition}

General trends over time in the total number of fish and invertebrate taxa are shown in Figs. 2 \& 3, respectively. Fish taxa were resolved to family level (Table 1), while invertebrate taxa were recorded as in Table 1.

Similarities in the total number of fish taxa existed between SS and TP plots (Fig. 2). The maximum number of taxa across all sites for both treatments ranged from 6 to 8 . Similarities were likewise apparent between EC and E plots.

Similar trends as described for fish were apparent in the numbers of invertebrate taxa (Fig. 3), with SS and TP having relatively higher values than EC and E plots. 
Table 1. Organisms found at the different sites and identified to family level where possible. Otherwise, the lowest possible taxonomic classification is indicated

\begin{tabular}{|c|c|c|c|c|}
\hline Group name & Phylum & Class & Order & Family \\
\hline Cyanobacteria & Cyanophyta & & & \\
\hline Chlorophyte & Chlorophyta & Chlorophyceae & $\begin{array}{l}\text { Caulerpales } \\
\text { Bryopsidales } \\
\text { Dascycladales } \\
\text { Siphonocladales }\end{array}$ & $\begin{array}{l}\text { Caulerpaceae } \\
\text { Halimedaceae } \\
\text { Dasycladaceae } \\
\text { Valoniaceae }\end{array}$ \\
\hline Phaeophyte & Phaeophyta & Phaeophyceae & $\begin{array}{l}\text { Dictyotales } \\
\text { Fucales }\end{array}$ & $\begin{array}{l}\text { Dictyotaceae } \\
\text { Sargassaceae }\end{array}$ \\
\hline Rhodophyte & Rhodophyta & Florideophyceae & $\begin{array}{l}\text { Ceramiales } \\
\text { Cryptonemiales } \\
\text { Nemaliales } \\
\text { Gelidiales } \\
\text { Gracilariales } \\
\text { Gigartinales }\end{array}$ & $\begin{array}{l}\text { Delesseriaceae } \\
\text { Rhodomelaceae } \\
\text { Halymeniaceae } \\
\text { Galaxauraceae } \\
\text { Gelidiaceae } \\
\text { Gracilariaceae } \\
\text { Hypneaceae } \\
\text { Solieriaceae }\end{array}$ \\
\hline Seagrass & Tracheophyta & & & \\
\hline Poriferan & & Demospongiae & & \\
\hline Milleporid & Cnidaria & Hydrozoa & Hydroida & Milleporidae \\
\hline Plumularid & Cnidaria & Hydrozoa & Hydroida & Plumularidae \\
\hline Stylasterid & Cnidaria & Hydrozoa & Hydroida & Stylasteridae \\
\hline Scyphozoan & Cnidaria & Scyphozoa & Rhizostomae & Cassiopeidae \\
\hline Gorgonacean & Cnidaria & Anthozoa & $\begin{array}{l}\text { Gorgonacea } \\
\text { Alcyonacea }\end{array}$ & $\begin{array}{l}\text { Isidiidae } \\
\text { Ellisellidae }\end{array}$ \\
\hline Alcyonacean & Cnidaria & Anthozoa & Alcyonacea & \\
\hline Helioporacean & Cnidaria & Anthozoa & Helioporacea & Helioporidae \\
\hline Stoloniferan & Cnidaria & Anthozoa & Stolonifera & Clavulariidae \\
\hline Zoanthid & Cnidaria & Anthozoa & Zoanthidea & \\
\hline Other zoantharian & Cnidaria & Anthozoa & $\begin{array}{l}\text { Actinaria } \\
\text { Ceriantharia } \\
\text { Corallimorpharia }\end{array}$ & \\
\hline Scleractinian & Cnidaria & Anthozoa & Scleractinia & \\
\hline Polyclad & Platyhelminthes & Turbellaria & Polycladida & \\
\hline Sabellid & Annelida & Polychaeta & Canalipalpata & Sabellidae \\
\hline Serpilid & Annelida & Polychaeta & Canalipalpata & Serpulidae \\
\hline Cirriped & Crustacea & Maxillipoda & & \\
\hline Stomatopod & Crustacea & Maxillipoda & Stomatopoda & Squillidae \\
\hline Decapod & Crustacea & Maxillipoda & Decapoda & $\begin{array}{l}\text { Alpheidae } \\
\text { Hippolytidae } \\
\text { Diogenidae }\end{array}$ \\
\hline Gastropod & Mollusca & Gastropoda & $\begin{array}{l}\text { Caenogastropoda } \\
\text { Caenogastropoda } \\
\text { Caenogastropoda } \\
\text { Anaspidea } \\
\text { Nudibranchia }\end{array}$ & $\begin{array}{l}\text { Strombidae } \\
\text { Cypraeidae } \\
\text { Vermetidae }\end{array}$ \\
\hline Bivalve & Mollusca & Bivalvia & Veneroida & Tridacnidae \\
\hline Asteroid & Echinodermata & $\begin{array}{l}\text { Stelleroidea } \\
\text { Stelleroidea } \\
\text { Stelleroidea }\end{array}$ & $\begin{array}{l}\text { Spinulosida } \\
\text { Valvatida } \\
\text { Valvatida }\end{array}$ & $\begin{array}{l}\text { Acanthasteridae } \\
\text { Oreasteridae } \\
\text { Ophiodiasteridae }\end{array}$ \\
\hline Ophiuroid & Echinodermata & Ophiuroidea & & \\
\hline Echinoid & Echinodermata & Echinoidea & $\begin{array}{l}\text { Diadematoida } \\
\text { Temnopleuroida } \\
\text { Temnopleuroida }\end{array}$ & $\begin{array}{l}\text { Diadematidae } \\
\text { Toxopneustidae } \\
\text { Temnopleuridae }\end{array}$ \\
\hline Holothuroid & Echinodermata & Holothuroidea & Apodida & Synaptidae \\
\hline $\begin{array}{l}\text { Crinoid } \\
\text { Ascidian }\end{array}$ & $\begin{array}{l}\text { Echinodermata } \\
\text { Chordata }\end{array}$ & $\begin{array}{l}\text { Crinoidea } \\
\text { Ascidiacea }\end{array}$ & & \\
\hline
\end{tabular}


Table 1 (continued)

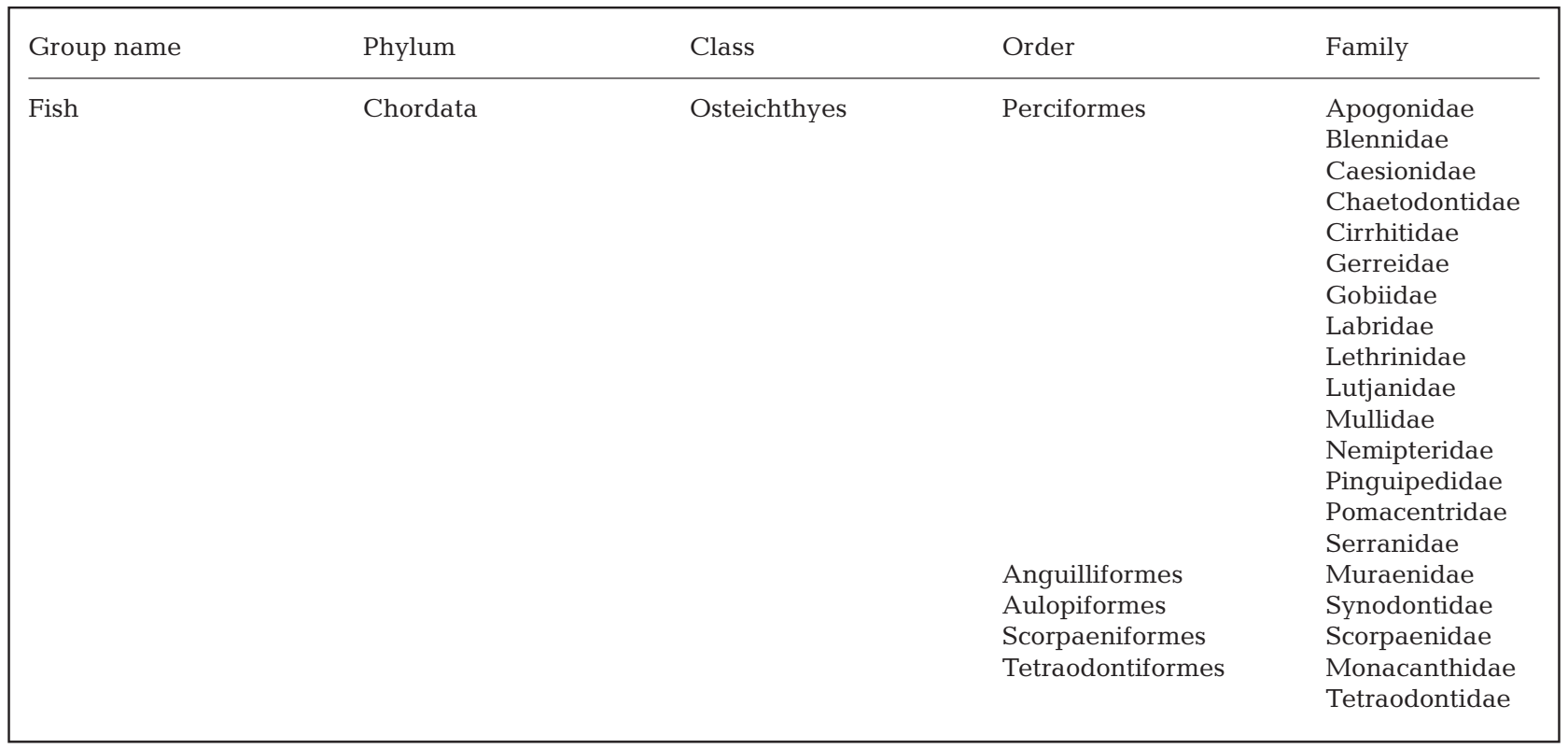

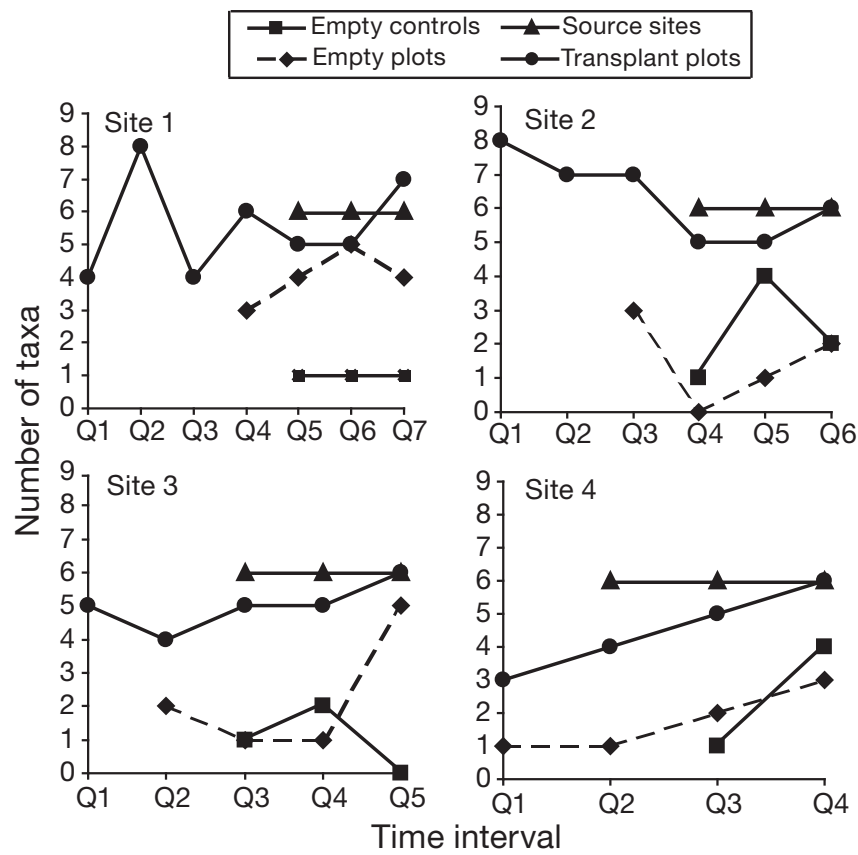

Fig. 2. Quarterly changes in number of fish taxa associated with different treatments at the different sites. An additional test for significant differences among treatments and over time, in the form of repeated measures ANOVA, was performed for the last 3 quarterly surveys at all sites (except the source sites). Details are given in the text

\section{Results of multivariate analyses}

Data on taxonomic composition and abundance of fish, invertebrates and algae (see Table 1) were com-

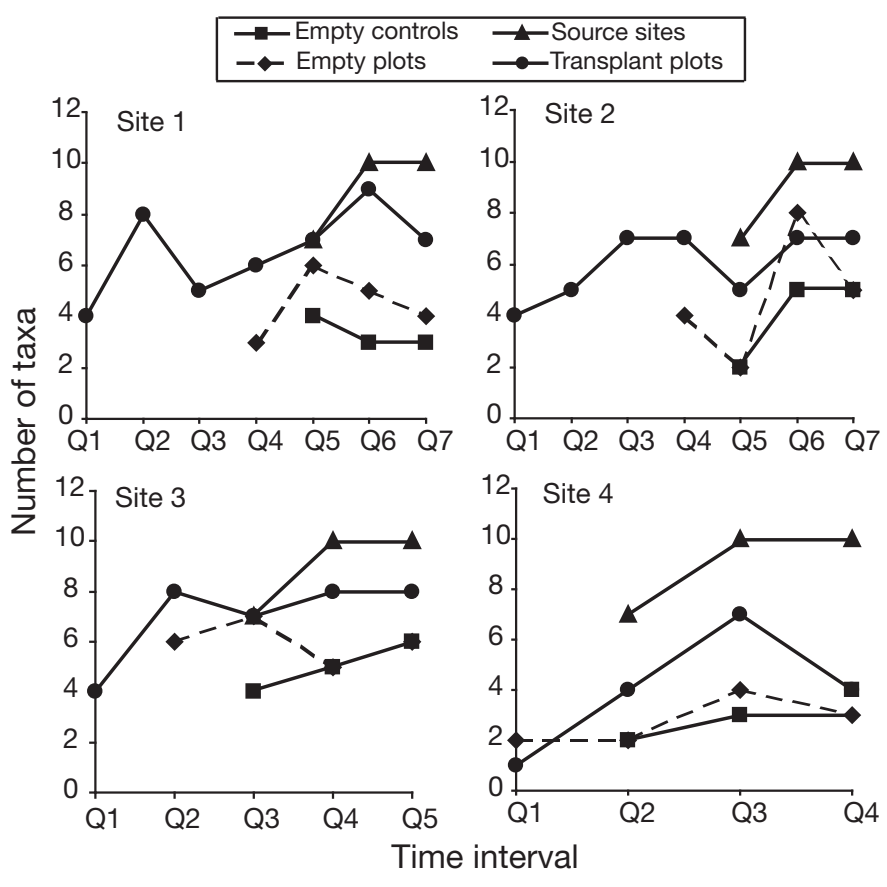

Fig. 3. Quarterly changes in number of benthic invertebrate taxa associated with different treatments at the different sites. An additional test for significant differences among treatments and over time, in the form of repeated measures ANOVA, was performed for the last 3 quarterly surveys at all sites (except the source sites). Details are given in the text

bined for the nMDS analysis in Fig. 4. ANOSIM revealed an overall significant difference $(p<0.05)$. Pairwise analyses indicated significant differences among treatments except between the EC and E plots. 


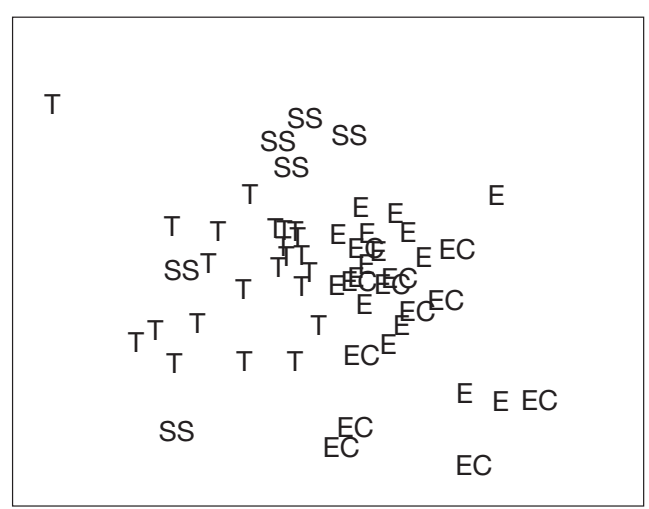

Fig. 4. Results of non-metric multidimensional scaling (nMDS) analysis of diversity comparing treatments. T: transplant plots, E: empty plots, EC: empty controls, SS: source sites. Stress $=0.19$

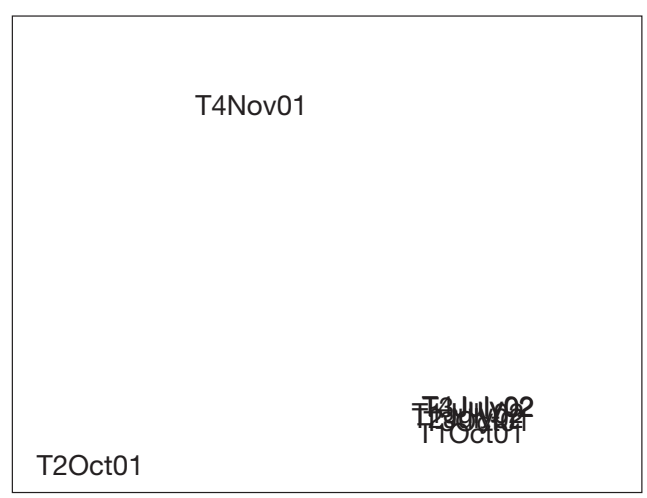

Fig. 5. Results of non-metric multidimensional scaling (nMDS) analysis of diversity comparing results from initial and final monitoring of the transplant plots. Stress $=0.1$

Diversity at the transplant plots and source sites differed significantly from the EC and E plots. Diversity was also significantly different between the TP and SS treatments.

For the comparison over time, abundance data for all taxonomic groups in all plots per treatment were used. The data collected right after transplantation were compared with those collected at the end of the experiment. Significant differences between these 2 times were detected only for the transplant plots (Fig. 5, ANOSIM: $\mathrm{p}<0.05$ ). No significant differences over time were detected for the other treatments (SS, E and $\mathrm{EC}$ ).

Tests using SIMPER revealed that the group occurring consistently within plots in the SS treatment was the Diadematidae (long-spined black sea urchin), contributing $19.3 \%$ of the similarity. For the TP, it was the Pomacentridae (damselfish, 15.8\%) and the Diadematidae $(14.7 \%)$. For the E plots, the groups contributing most to the similarity within the treatment were the
Faviidae $(20.9 \%)$ and the Poritidae $(18.9 \%)$, both being families of hard corals. The same groups accounted for the similarity within the EC plots, i.e. Poritidae (20.9\%) and Faviidae (17.6\%).

SS plots differed consistently from the other treatments concerning the Poritidae, which contributed $8.2 \%$ of the difference when compared with the TP plots, $9.2 \%$ with the E plots, and $9 \%$ with the EC plots. As emphasized in the 'Materials and methods' section, only new recruits of this family of coral were counted. They were more numerous in the SS treatment than in the others (mean abundances were 10.39 for SS, 0.62 for $\mathrm{TP}, 0.88$ for $\mathrm{E}$ and 0.51 for $\mathrm{EC}$ ). In addition, the presence of higher numbers of sea urchins of the family Diadematidae also distinguished the SS plots from the E and EC plots (7\% and 7.3\%, respectively). Mean abundances were 6.33 for SS, 1.2 for E and 1.1 for EC. Comparing the TP with the E and EC treatments, the group accounting for the greatest difference was the Pomacentridae, with differences of $6.8 \%$ (E) and $7.9 \%$ (EC). The TP plots had greater abundances of damselfish (mean abundance was 2.05, compared with 0.25 for $\mathrm{E}$ and 0.07 for EC). In addition, TP plots also harbored higher numbers of Diadematidae compared with the E plots (contributing $6.2 \%$ of the difference) and the EC plots $(6.7 \%)$. Mean abundances were 2.8 for TP, 1.2 for $\mathrm{E}$ and 1.1 for EC.

\section{Results of repeated measures ANOVA}

Fish

Results of repeated measures ANOVA (Table 2) showed that the data set satisfied the assumption of compound symmetry (Mauchly's sphericity criterion $\mathrm{W}=0.970, \mathrm{p}>0.05)$; thus, there was no need to proceed with the analysis under relaxed assumptions (i.e. using Greenhouse-Geisser- and Huynh-Feldtcorrected ANOVAR). The analysis revealed a marginally significant among-site difference $(p=0.045)$ and a highly significant among-treatment difference $(p<$ 0.001). Fish diversity in TP plots was significantly different from EC and E plots. The effect of the interaction of Site and Treatment as well as the within-subject factors on fish diversity was not significant. Post-hoc comparisons using Helmert contrasts showed no significant differences over time. Tukey's Honestly Significant Difference (HSD) test revealed that Site 1 (western side) was significantly more diverse than Site 2 (southeastern side), but neither was different from Sites 3 and 4 . The multiple comparisons test also confirmed that fish diversity in the TP treatment was significantly higher than in the EC and $\mathrm{E}$ treatments. 
Table 2. Results of repeated measures ANOVA comparing number of taxa and abundance over time at different sites and different treatments for fish and benthos. EC: empty controls, E: empty plots, TP: transplant plots. ${ }^{*} \mathrm{p}<0.05$

\begin{tabular}{|c|c|c|c|c|}
\hline Effect & MS & $F$ & df & $\mathrm{p}$ \\
\hline \multicolumn{5}{|l|}{ Fish } \\
\hline Site & 3.272 & 2.849 & 3 & $0.045^{*}$ \\
\hline Treatment & 61.847 & 53.867 & 2 & $0.000^{*}$ \\
\hline Site $\times$ Treatment & 1.489 & 1.297 & 6 & 0.272 \\
\hline Time & 0.792 & 0.946 & 2 & 0.391 \\
\hline Time $\times$ Site & 1.211 & 1.447 & 6 & 0.202 \\
\hline Time $\times$ Treatment & 0.05556 & 0.066 & 4 & 0.992 \\
\hline Time $\times$ Site $\times$ Treatment & 0.873 & 1.044 & 12 & 0.414 \\
\hline \multicolumn{5}{|c|}{ Mauchly's sphericity criterion, $W=0.970(\mathrm{p}=0.401)$} \\
\hline \multicolumn{5}{|l|}{ Benthic invertebrates } \\
\hline Site & 4.543 & 1.460 & 3 & 0.234 \\
\hline Treatment & 51.838 & 16.662 & 2 & $0.000^{*}$ \\
\hline Site $\times$ Treatment & 4.548 & 1.462 & 6 & 0.207 \\
\hline Time & 0.685 & 0.589 & 2 & 0.557 \\
\hline Time $\times$ Site & 1.543 & 1.326 & 6 & 0.251 \\
\hline Time $\times$ Treatment & 1.907 & 1.639 & 4 & 0.169 \\
\hline Time $\times$ Site $\times$ Treatment & 1.006 & 0.864 & 12 & 0.585 \\
\hline \multicolumn{5}{|c|}{ Mauchly's sphericity criterion, $W=0.977(\mathrm{p}=0.496)$} \\
\hline \multicolumn{5}{|l|}{ Tukey's HSD } \\
\hline \multicolumn{5}{|l|}{ Fish } \\
\hline Site & \multicolumn{4}{|c|}{$\begin{aligned} \text { Site } 2=\text { Site } 4 & =\text { Site } 3 \\
\text { Site } 4 & =\text { Site } 3=\text { Site } 1\end{aligned}$} \\
\hline Treatment & $\mathrm{EC}=\mathrm{E} \neq \mathrm{T}$ & & & \\
\hline \multicolumn{5}{|l|}{ Benthic invertebrates } \\
\hline Treatment & $\mathrm{EC}=\mathrm{E} \neq \mathrm{T}$ & & & \\
\hline
\end{tabular}

Benthic invertebrates

Mauchly's criterion for the benthic diversity data ( $W=0.977, \mathrm{p}=0.496$, Table 2 ) indicated acceptance of the compound symmetry assumption. For this data set, only the treatment factor showed a significant difference. Using Tukey's HSD test, as with the fish diversity data, the TP plots were shown to have a significantly higher taxonomic diversity than both the EC and the E plots $(p<0.001)$. No significant interaction effects or within-subject effects were detected. Helmert contrasts revealed no significant differences over time.

\section{DISCUSSION}

Higher numbers of taxa and greater abundances of organisms (particularly fish and invertebrates) were observed over time in the plots that contained transplanted live corals compared with those without. This suggests that the introduction of additional adult coral colonies enhanced the occurrence of these organisms.
Overall survivorship of the coral transplants by the end of the experiment was $94 \%$ for Acropora palifera, $85 \%$ for Porites lobata, and $83 \%$ for $P$. cylindrica. Hence, a significant amount of live tissue cover was maintained throughout. Had substantial mortality occurred, the dead corals would have been covered by a variety of algae, mostly turf and filamentous forms (Yap \& Molina 2003, Yap 2004). These would then have attracted a different suite of organisms from those observed in this study (Lindahl et al. 2001).

The level of diversity in the transplant plots did not attain that observed in the source sites for the duration of this experiment, though the initial trends are encouraging. The difference in depth between the source and the degraded sites that received the other treatments is to be taken into consideration as well. This was inevitable because the degraded portions, located in the shallower reef flat areas, are normally subjected to a lot of human disturbance compared with the deeper zones where healthier coral cover is normally found (H.T. Yap pers. obs. in various reefs).

The lack of statistically significant differences between the EC and the E plots in terms of diversity is important. The E plots were interspersed among the TP plots, while the EC were situated at least $100 \mathrm{~m}$ away. The results indicate that no significant exchange of organisms occurred between the E and TP plots despite their proximity (on the order of a few meters). The differences in species numbers between the 2 treatments despite spatial similarities, plus the absence of a statistical difference between EC and E plots, represents evidence that the apparent enhancement of diversity was, indeed, due to the additional presence of coral transplants in the TP plots. This is further reinforced by the significant changes in diversity detected in the TP plots by the nMDS analysis between the start and the end of the experiment. However, repeated measures ANOVA did not detect significant differences from one interval to the next for the 3 specific months examined.

The movement of organisms into the transplant plots presumably included settlement of larvae and juveniles, as well as adult immigration. Organisms of any size were observed to occur in all plots, with or without transplants (excluding the coral transplants themselves). Obviously, larval recruitment could be documented once individuals attained a visible size. The addition of species documented here includes not only the long-term process whereby individuals are established and remain as part of the community (recruitment), but also the transient process where organisms enter the plots, but leave after a period of time as part of their sporadic or migratory movements. 
When transplant plots were compared with empty plots and empty controls, the largest differences were due to greater numbers in the former of damselfish (Pomacentridae) and sea urchins (Diadematidae). Thus, the introduction of additional live coral colonies helped to increase abundances of these organisms among others. Fish depend on corals as a source of refuge and food (Sano et al. 1987, Bouchon-Navarro 1986 as cited in Lindahl et al. 2001). An increase in coral cover leads to an increased number of fish, not only for corallivores but also for herbivores and omnivores (Sano 2000, Cabaitan et al. 2008). The same probably holds true for sea urchins, with the additional structural complexity provided by living coral serving as an attractant, thereby explaining their relatively greater abundance in the source and transplant plots.

The sea urchin, Diadema, is an algal grazer (Steneck \& Dethier 1994). Its presence in the Caribbean and other similar regions is associated with the occurrence of relatively high coral abundance since its feeding behavior can lead to a decrease in algal cover, thereby helping to reduce potential competition of algae with coral recruits (Bellwood et al. 2004, Mumby et al. 2007). It may have the same effect in coral-dominated areas in the Philippines.

The source sites, being less impacted, still maintained higher levels of coral recruitment (family Poritidae) compared with the other treatments. As mentioned, they were also characterised by greater abundances of sea urchins. However, the groups contributing most to the similarity within the degraded plots without intervention ( $\mathrm{E}$ and $\mathrm{EC}$ ) were also coral recruits of the families Faviidae and Poritidae, respectively. This is an indication that recruitment of hard coral proceeds even in these sub-optimal environments, though at levels much lower than at the source sites (Coles \& Brown 2007).

The results of this manipulative experiment suggest that intervention using coral transplantation at the scales involved resulted in marked changes in community composition and abundance. Corals facilitate both processes of recruitment (Buchheim \& Hixon 1992 as cited in Lindahl et al. 2001) and biomass production (Carr \& Hixon 1997) by providing space for settlement, growth and reproduction. In contrast, a decrease in coral cover (with a concomitant increase in dead substrate) can result in a decline in both benthic (Caley et al. 2001) and pelagic assemblages (Syms 1998, Booth \& Beretta 2002).

While providing shelter, corals also set the stage for biological interactions such as competition and predation (Buchheim \& Hixon 1992 as cited in Lindahl et al. 2001, Adams \& Ebersole 2002). In a study by Connell and Kingsford (1998), the number of predators was associated with the percentage of live coral cover. The number of predators along with predatory activity was lower when there was a drop in coral cover. It could, thus, be inferred from these results that there are more resources found in areas with corals compared to those with dead or bare substrates.

Some studies, however, have yielded different results. There are certain thresholds below which marine organisms are able to persist for a period of time (Syms \& Jones 2000) despite the changes in the reef habitat. For example, a study by Spalding \& Jarvis (2002) indicated that, with increased coral mortality, the number of corallivorous and coral-nesting fish species decreased, but invertebrate feeders increased. Furthermore, wrasses (family Labridae) were more inclined towards dead substrates (Fulton \& Bellwood 2002). Some fish species are not disadvantaged by a decrease in live coral cover, such as herbivores that benefit from enhanced algal growth on the dead corals (Lindahl et al. 2001). Thus, the nature of the association of the reef community with the biogeologic structure of corals is significant, but may be divergent for different components of the community.

\section{CONCLUSION}

Coral transplantation in Padre Burgos, Quezon, in the Philippines enhanced the process of community establishment, and hence the increase in local diversity at the scales used (Connell \& Kingsford 1998, Carr et al. 2002). This was achieved primarily by the provision of structural complexity and live coral cover at the scale of the microhabitat. When compared with dead substrates or barren areas, the coral transplants provided additional resources and shelter for different species.

Since reefs in the Philippines are part of the acknowledged center of shallow-water diversity of fish (Carpenter \& Springer 2005), results of this study are significant for reasons of environmental conservation and protection. Ecological processes in Philippine reefs should also be similar to those in other parts of the Indo-West Pacific region, and insights gained about these dynamics are relevant to action concerning coral reef ecosystems worldwide.

Acknowledgements. The author is indebted to a number of individuals who, at various stages, have helped with the field work, data analysis and discussion of ideas, especially R. M. Dizon, A. Reyes, and R. Baua. This study was funded by the Bureau of Agricultural Research of the Department of Agriculture, Philippines. The experiments comply with the current laws of the country in which the experiments were performed. This is contribution number 375 of the Marine Science Institute, University of the Philippines. 


\section{LITERATURE CITED}

Adams AJ, Ebersole JP (2002) Use of back-reef and lagoon habitats by coral reef fishes. Mar Ecol Prog Ser 228:213-226

Bellwood DR, Hughes TP, Folke C, Nyström M (2004) Confronting the coral reef crisis. Nature 429:827-833

$>$ Booth DJ, Beretta GA (2002) Changes in a fish assemblage after a coral bleaching event. Mar Ecol Prog Ser 245: 205-212

Bruno JF, Selig ER (2007) Regional decline of coral cover in the Indo-Pacific: timing, extent, and subregional comparisons. PLoS One 2(8):e711. doi:10.1371/journal.pone.0000711

Cabaitan PC, Gomez ED, Aliño PM (2008) Effects of coral transplantation and giant clam restocking on the structure of fish communities on degraded patch reefs. J Exp Mar Biol Ecol 357:85-98

Caley MJ, Buckley KA, Jones GP (2001) Separating ecological effects of habitat fragmentation, degradation, and loss on coral commensals. Ecology 82:3435-3448

> Carpenter KE, Springer VG (2005) The center of the center of marine shore fish biodiversity: the Philippine Islands. Environ Biol Fishes 72:467-480

> Carr MH (1989) Effects of macroalgal assemblages on the recruitment of temperate zone reef fish. J Exp Mar Biol Ecol 126:59-76

Carr MH, Hixon MA (1997) Artificial reefs: the importance of comparisons with natural reefs. Mar Ecol Prog Ser 22: 28-33

> Carr MH, Anderson TW, Hixon MA (2002) Biodiversity, population regulation, and the stability of coral-reef fish communities. Proc Natl Acad Sci USA 99:11241-11245

> Chapman MG (2002) Early colonization of shallow subtidal boulders in two habitats. J Exp Mar Biol Ecol 275:95-116

Clarke KR (1993) Non-parametric multivariate analyses of changes in community structure. Aust J Ecol 18:117-143

Clarke KR, Gorley RN (2001) PRIMER v5: User manual / tutorial. PRIMER-E, Plymouth

Coles SL, Brown EK (2007) Twenty-five years of change in coral coverage on a hurricane impacted reef in Hawai'i: the importance of recruitment. Coral Reefs 26:705-717

> Connell SD, Kingsford MJ (1998) Spatial, temporal and habitat-related variation in the abundance of large predatory fish at One Tree Reef, Australia. Coral Reefs 17:49-57

Edwards AJ, Gomez ED (2007) Reef restoration concepts and guidelines: making sensible management choices in the face of uncertainty. Coral reef targeted research \& capacity building for management (CRTR) program, St. Lucia, Australia

Fulton CJ, Bellwood DR (2002) Patterns of foraging in labrid fishes. Mar Ecol Prog Ser 226:135-142

Hixon MA, Carr MH (1997) Synergistic predation, density dependence and population regulation in marine fish. Science 277:946-949

Levin PS, Hay ME (2002) Fish-seaweed association on temperate reefs: Do small-scale experiments predict largescale patterns? Mar Ecol Prog Ser 232:239-246

Lindahl U, Öhman MC, Schelten CK (2001) The 1997/1998 mass mortality of corals: effects on fish communities on a Tanzanian coral reef. Mar Pollut Bull 42:127-131

Editorial responsibility: Charles Birkeland, Honolulu, Hawaii, USA
Lockwood JL, Pimm SL (1999) When does restoration succeed? In: Weiher E, Keddy P (eds) Ecological assembly rules: perspectives, advances, retreats. Cambridge University Press, Cambridge, p 363-391

- Mumby PJ, Hastings A, Edwards HJ (2007) Thresholds and the resilience of Caribbean coral reefs. Nature 450:98-101

> Nyström M, Folke C, Moberg F (2000) Coral reef disturbance and resilience in a human-dominated environment. Trends Ecol Evol 15:413-417

Öhman MC, Rajasuriya A (1998) Relationships between habitat structure and fish communities on coral and sandstone reefs. Environ Biol Fishes 53:19-31

Öhman MC, Rajasuriya A, Ólafsson E (1997) Reef fishes in northwestern Sri Lanka: distribution patterns and influences of fishing practices. Environ Biol Fishes 49:45-61

$>$ Pandolfi JM, Jackson JBC (2006) Ecological persistence interrupted in Caribbean coral reefs. Ecol Lett 9:818-826

> Potvin C, Lechowicz MJ, Tardif S (1990) The statistical analysis of ecophysiological response curves obtained from experiments involving repeated measures. Ecology 71 : 1389-1400

- Rinkevich B (2005) Conservation of coral reefs through active restoration measures: recent approaches and last decade progress. Environ Sci Technol 39:4333-4342

Sano M (2000) Stability of reef fish assemblages: responses to coral recovery after catastrophic predation by Acanthaster planci. Mar Ecol Prog Ser 198:121-130

Sano M (2001) Short-term responses of fishes to macroalgal overgrowth on coral rubble on a degraded reef at Iriomote Island, Japan. Bull Mar Sci 68:543-556

Sano M, Shimizu M, Nose Y (1984) Changes in structure of coral reef fish communities by destruction of hermatypic corals: observational and experimental views. Pac Sci 38: $51-79$

Sano M, Shimizu M, Nose Y (1987) Long-term effects of destruction of hermatypic corals by Acanthaster planci infestation on reef fish communities at Iriomote Islands, Japan. Mar Ecol Prog Ser 37:191-199

- Spalding MD, Jarvis GE (2002) The impact of the 1998 coral mortality on reef fish communities in the Seychelles. Mar Pollut Bull 44:309-321

Steneck RS, Dethier MN (1994) A functional group approach to the structure of algal-dominated communities. Oikos 69:476-498

Syms C (1998) Disturbance and the structure of coral reef fish communities on the reef slope. J Exp Mar Biol Ecol 230: 151-167

Syms C, Jones GP (2000) Disturbance, habitat structure, and the dynamics of a coral-reef fish community. Ecology 81: $2714-2729$

Yap HT (2004) Differential survival of coral transplants on various substrates under elevated water temperatures. Mar Pollut Bull 49:306-312

Yap HT, Molina RA (2003) Comparison of coral growth and survival under enclosed, semi-natural conditions and in the field. Mar Pollut Bull 46:858-864

- Yap HT, Alvarez RM, Custodio HM, Dizon RM (1998) Physiological and ecological aspects of coral transplantation. J Exp Mar Biol Ecol 229:69-84

Submitted: April 7, 2008; Accepted: July 16, 2008

Proofs received from author(s): November 7, 2008 